\title{
HRM in the global information technology (IT) industry: Towards Multivergent configurations in strategic business partnerships
}

\author{
Authors: Ashish Malik, Vijay Pereira, Pawan Budhwar
}

\begin{abstract}
This paper responds to calls for theory development in relation to processual and meso-level explanations of 'crossvergence' in strategic partnerships. It contributes by reviewing the extant literature on convergence-divergence-crossvergence theory in the context of the global information technology (IT) industry and argues for the presence of 'multivergence' or 'multiple configurations of crossvergence' in an industry sector that relies extensively on strategic business partnerships. We posit and argue that the relevance of multivergence extends beyond the global and offshore IT industry to include strategic partnerships in offshoring in services and manufacturing firms. Overall, this paper identifies the processes and meso-level factors that lead to multivergence in IHRM practices and presents future research directions and ideas on this topic.
\end{abstract}

Keywords: Convergence, Divergence, Crossvergence, Multivergence, Emerging markets, Strategic business partnerships.

\section{Introduction}

This paper contributes to the literature through the development of a conceptual framework based on our review of two related fields: strategic business partnerships (Gomes, Cohen, \& Mellahi, 2011; Pak, Ra, \& Lee, 2015) and the convergence-divergence-crossvergence (CDC) thesis (Ralston, Gustafson, Cheung, \& Terpstra, 1993; Ralston, Holt, Terpstra, \& Yu, 1997; Ralston, 2008). We then investigate the applications of our framework for international human resource management (IHRM) based on our empirical work from the global information technology (IT) industry, as a context, which is at the interface of these three overarching literatures. The CDC thesis examines the factors that influence and change managerial and cultural values over a period of time through processes of convergence, divergence or crossvergence. Convergence involves developing a 'common or similar' political, economic and managerial value systems, through the processes of globalisation (Brewster et al., 2015; Harbison \& Myers, 1959; Kerr et al., 1960), which in turn results in similar management practices or adopting a 'universalistic' set of values by a firm in a host nation (Rowley and Benson 2000). Divergence occurs when management practices in two countries differ due to differences in national regulations, government policies, values, culture and beliefs as well as national educational systems (Brewster et al., 2015; Hollingsworth \& Streeck, 1994). Crossvergence, as defined by Ralston et al., (1997: 183) is 'when an individual incorporates 
both national culture influences and economic ideology influences synergistically to form a unique value system that is different from the value set supported by either national culture or economic ideology'. Crossvergent values, we note, are a distinctive amalgam emerging through the complex interactions between the dynamic and stabilisation processes of convergence and divergence.

We argue that the CDC thesis is relevant to the concept of strategic partnerships, which, in the main, focuses on mergers, acquisitions, strategic alliances (Gomes, Angwin, Weber \& Tarba, 2013; Gomes, Angwin, Peter, \& Mellahi, 2012; Tarba \& Cooper, 2016) or other forms of partnerships such as strategic international offshore outsourcing of services (Carmel \& Agarwal, 2002; Fitzgerald \& Willcocks, 1994; Holcomba \& Hitt, 2007; Kedia \& Lahiri, 2007; Marcolin, 2006; Søderberg, Krishna, \& Bjørn, 2013; Quinn \& Hilmer, 1994). On the premise that by its very nature, partnering firms need to develop mutual cooperation, commitment and collaboration for engaging in participative decision-making between the partners, we argue that by developing such relational and hierarchical contracts, there is effective sharing of knowledge, resources, business and HRM practices that help create and realise value through such strategic partnerships (Contractor \& Woodley, 2015; Henderson, 1990).

Researchers focusing on CDC have tended to focus on macro-, group-, and micro-level influences on management practices (Jaeger, Kim \& Butt, 2016; Ralston, 2008; Ralston et al., 1997) and there is little understanding of meso-level interactions (between the industry and organisational levels). Further, as a context, strategic business partnerships play out extensively in the global information technology (IT) industry in the form of client-vendor relationships in offshore outsourcing contracts, and hence this is an important and interesting research area that needs theory development, as discussed here. First, from a CDC thesis perspective, strategic partnerships are influenced by a range of cultural, national business systems and institutional considerations (Ahlstrom, Levitas, Hitt, Dacin, \& Zhu, 2014; Chand \& Katou, 2012; Ralston, 2008). Second, the IT industry, a born-global industry, is often faced with challenges of culture and change across borders in managing strategic partnerships (Gomes, Cohen, \& Mellahi, 2011; Pak, Ra, \& Lee, 2015). Third, there is growing body of literature that focus on the CDC thesis and its impact on IHRM practices in MNCs, but there is a need to critically review this literature to develop future research propositions. Examples of the CDC research are evident in research from the US (e.g. Briscoe, Schuler, \& Tarique, 2012; Entrekin \& Chung, 2001; Ramamoorthy, Gupta, Sardesai \& Flood, 2005), the European Union and Australia (Brewster, 
Sparrow, \& Harris. 2005; Dickmann, Brewster, \& Sparrow, 2008; Dowling, Festing, \& Engle, 2013; Jackson, 2002; McGraw, \& Pereetz, 2011), as well as emerging markets, such as Brazil, India, China and South Africa (Budhwar, 2012; Cooke, 2014; Howritz, Kamoche, \& Chew, 2002; Jackson, Louw, \& Zhao, 2013; Kim \& Gao, 2010; Tung \& Haq, 2012; Vance, Chow, Paik, \& Shin, 2013; Zhou, Zhang \& Liu, 2012; Zhang, 2012). Thus, we argue that while most research on common forms of strategic partnerships such as strategic alliances, joint ventures and mergers and acquisitions has highlighted the role of certain HRM practices in effectively managing such partnerships (Aklamanu et al., 2016; Sarla et al., 2016; Tarba et al., 2017; Vasilaki et al., 2016; Xing et al., 2016; Zhang et al., 2015), there is limited research that investigates the role of HRM in strategic business partnerships such as in the case of strategic offshore outsourcing of services (Carmel \& Agarwal, 2002; Fitzgerald \&Willcocks, 1994; Holcomb \& Hitt, 2007; Kedia \& Lahiri, 2007; Marcolin, 2006; Søderberg, Krishna \& Bjørn, 2013; Quinn \& Hilmer, 1994), which typifies the global IT industry. Further, in a meta- review of inter-organisational relationships, Parmigiani and Riverra-Santos (2011) argued that firms that enter into inter-organisational relationships do so for co-exploration or co-exploitation. They further argue that theoretical lens underpinning such partnerships are grounded in theories such as transaction-cost economics, resource-based view, organisational learning, institutional and resource dependency, to name a few. By focusing on this industry we make a case through our future research propositions and ideas for its application in similar industries. Overall, this study attempts to integrate the above discussed three streams of research and develops a holistic conceptual framework for understanding this. We contribute to the literature by arguing that firms in such strategic business partnerships present opportunities to study multiple configurations of crossvergence or what we term as 'multivergence', due to meso-level influences that are inherent in this industry.

More specifically, we present evidence of this phenomenon through the growing literature and our collective research experiences from the global and offshore IT industry. We argue that in line with configurational approaches, the concept of equifinality is highly relevant to our conceptualisation (e.g. Fiss, 2007) because "a system can reach the same final state, from different initial conditions and by a variety of different paths" (Katz \& Kahn, 1978: 30). A configurational approach is logical as firms in the global IT industry have implemented a number of crossvergent IHRM practices due to (1) converging IT industry software and product development and delivery standards; (2) divergent influences of business practices in their network of strategic partnerships; and (3) divergent influences in technical practices of its 
clients and network partners. Therefore, a meso-level analysis incorporating industry-and firmlevel interactions is logical. Strategic business partnerships in off-shore outsourcing, requires hierarchical and relational governance norms for managing the partnership (Blumberg et al., 2008; Croom, 2001). We believe that through our review, future research propositions and ideas from this research have applications that can be generalised to other born-global industry sectors such as the electronics and components manufacture (ECM), IT/BPO and pharmaceuticals. We make this argument as a number of developed nation MNCs have significant cross-border subsidiaries and third party offshore outsourcing operations in emerging markets such as India and China. The opportunity for understanding sociocultural, business ideological and industry-level differences and similarities is fertile in such contexts as well as presents an exciting and a promising area for further research. As strategic partnerships often invoke changes to people's values, behaviours and emotions (Tarba et al., 2016), studying such partnerships from an IHRM and CDC perspective is critical. To this end, considering the gaps in the literature regarding strategic business partnerships, especially from strategic offshore outsourcing of services (Kedia \& Lahiri, 2007) and the CDC thesis (Al-Ariss \& Sidani, 2014, 2016a, b; Ralston, 2008: 37; Witt, 2008: 50), we present a processual and mesolevel understanding of crossvergence (and multivergence) in IHRM practices and attempt to answer the following research questions:

1. What are the meso-level influences of crossvergence (and multivergence) in strategic business partnerships in the global IT industry; and

2. How do meso-level influences shape IHRM practices in strategic business partnerships in the global IT industry?

In doing so, we develop a conceptual framework linking the convergence-divergencecrossvergence-multivergence (CDCM) thesis within a collaborative partnership perspective in the global IT industry through the lens of IHRM. The rest of the paper is structured as follows. We begin by reviewing the literature on strategic business partnerships and its impact on IHRM practices. This is followed by a review of literature of the CDC thesis and its impact on HRM practices. Next, utilising Pereira, Munjal and Nandakumar's (2015) categorisation of a strategic partnership relationships within an offshoring context, we portray HRM practices through five CDCM scenarios. Further, in the context of strategic partnerships, the CDCM thesis is further explored in-depth, which leads to the development of two conceptual frameworks for analysing configurations of crossvergence (and multivergence). This is based on meso-level (industry 
and firm-level) factors that are central in the strategic business partnerships in the context of offshore outsourcing to third party service providers. We propose future research propositions for strategic business partnerships in the context of offshore outsourcing in the global IT industry.

\section{Strategic Partnerships and HRM practices}

Recent studies have highlighted the need for research focusing on the role of HRM practices in effectively managing strategic partnerships such as mergers and acquisitions (M\&A), strategic alliances (SA) and joint venture (JV) partnerships. There is also a further need to investigate how such strategic partnerships impact current HRM practices in the partnering firms as there are several challenges to manage at the interface of two or more strategic partnerships (Gomes, Angwin, Weber, \& Tarba, 2013; Gomes, Angwin, Peter, \& Mellahi, 2012; Tarba \& Cooper, 2016). In M\&A-the most common form of strategic partnership-there is relatively limited attention being paid to HRM issues (Budhwar, Varma, \& Katou, 2009; Nikandrou \& Papalexandris, 2007) and even more so in case of cross-border partnerships (Weber \& Tarba, 2010). In business partnerships, firms have to constantly manage and exploit common resources, knowledge and specialist practices that are accessible to them. Stokes, Liu, Smith, Leidner, Moore, and Rowland (2015) noted flexible and resilient HRM practices as critical in enabling a successful relationship in a cross-border Sino-German collaboration. Friedman, Carmeli, Tishler, and Shimizu (2015) highlight the importance of behavioural integration at an individual and organisational level in strategic partnerships, whilst Angwin, Mellahi, Gomes, and Peter (2014) highlight the importance of the process and content of communication in achieving post-merger integration (PMI) success. Further, Yahiaoui, Chebbi, \& Weber (2016) discuss about the ability of a firm to integrate knowledge between the partnering firms as a critical enabler of PMI success. Also in a PMI context, Vasilaki, Tarba, Ahammad, and Glaister (2016) found the HRM practices of communication, employee involvement, teamwork, and training and development are important in building necessary employee behaviours that are relevant for PMI success.

Although there are studies focusing on JV, M\&A and SAs as forms of business partnerships where a critical role is played by HRM in making these partnerships successful and effective (Aklamanu et al., 2016; Sarla et al., 2016; Tarba et al., 2017; Vasilaki et al., 2016; Xing et al., 2016; Zhang et al., 2015), there is relatively limited research that investigates the role of HRM in strategic business partnerships such as 'international outsourcing or offshore outsourcing of 
services' (IOS) (Carmel \& Agarwal, 2002; Fitzgerald \& Willcocks, 1994; Kedia \& Lahiri, 2007; Marcolin, 2006; Søderberg, Krishna \& Bjørn, 2013; Quinn \& Hilmer, 1994). Such partnerships are typically found in high-technology services industries such as in the global IT industry as well as bio-technology and manufacturing sector firms in ECM and pharmaceuticals. For example, Foxconn in China and other component manufacturers in SouthEast Asia and at global contract drug manufacturing sites of large pharma MNCs. These partnerships, are strategic in nature and differ significantly from M\&As, JVs and SAs in that they are typically governed through an arm's length relationship but it may also involve developing deeper and transformational consulting relationships over longer periods of time. What is distinctively different in such partnerships, relative to M\&As, JVs and SAs is that commercial interests are only sustained if the service provider can offer high performance services to the contracting party. In such partnerships, the service provider's capability is central in a successful and high performing partnership. What is also evident in the above studies is that the focus is mostly on macro- and micro-level explanations for successfully managing such partnerships. There is relatively limited research that maps the impact of mesolevel influences on strategic partnerships such as IOS in a cross-border context, linked to the CDC thesis and the role of HRM practices in managing such a partnership.

\section{Convergence-Divergence-Crossvergence-Multivergence Research}

The CDC theory, originally developed by Ralston et al. (1993) has since its evolvement, received several calls for undertaking additional research (Ralston, 2008; Witt, 2008) highlighting the need for longitudinal designs and multi-level analyses, preferably in the same study. There are some who have sought clarification on what the term exactly means. For example, Witt (2008), cautions that we need to seek a better understanding of what the term crossvergence means and does national culture and economic ideology serve as good influences for developing managerial values that are central in studies of crossvergence? In a similar vein, Mcgaughey and De Ceiri (1999) have noted that the assumptions of Ralston et al.'s (1997) framework are overly simplistic, as they assume the drivers for divergence in values are mainly due to differences in socio-cultural factors and convergence in values occurs due to similarities in technological adoptions and business ideologies and practices. Similar to research on strategic business partnerships noted above, Mcgaughey and De Ceiri highlight a need for other endogenous and exogenous 'middle' or meso-level factors such as human resource practices and legislation, customer and supplier influences, respectively, for 
explaining convergence, divergence or indeed crossvergence. Further, the authors demonstrate how meso-level factors can variously interact with macro and micro-level factors and have an impact on the CDCM outcomes. Witt (2008) also argues for the need for a better understanding of the processes that cause changes from a convergence and/or divergence approach to crossvergence. It is with this processual gap in mind that this study pursues the conceptualisation of multivergence. Therefore, by focusing on a meso-level understanding in the context of collaborative partnerships within the global IT industry, this study uncovers various configurations of crossvergence (or what we refer to as multivergence). To observe the differences in emerging models of IHRM, we concur with the view that firms can be collectively grouped at an industry level (Carrol \& Hannan, 1995). Further, studies of industry evolution and HRM practices suggest that there are some industry-specific evolutionary phases and differences that impact the nature and extent of CDCM in HRM systems (e.g., Budhwar \& Sparrow, 2002) and that in the context of born-global industries, such as the global IT industry, where collaborative strategic partnerships is the norm, it is likely that such impacts are observable and sustained.

\section{1 'Crossvergence' research in the International HRM context}

We acknowledge the literature on crossvergence in the context of international HRM, (see e.g. Entrekin \& Chung, 2001; Howritz, Kamoche \& Chew, 2002; Jackson, 2002; Jackson, Louw \& Zhao, 2013; Kim \& Gao, 2010; McGraw \& Pereetz, 2011; Ramamoorthy, Gupta, Sardesai \& Flood, 2005; Tung \& Haq, 2012; Vance, Chow, Paik \& Shin, 2013; Zhou, Zhang \& Liu, 2012; Zhang, 2012) however, literature in this area is still evolving and further research is needed. The rationale being that through the development of such crossvergent, relational and hierarchical contracts, there is effective sharing of knowledge, resources, business and HRM practices that help create and realise value, in the context of this research paper, strategic partnerships (Contractor \& Woodley, 2015; Henderson, 1990; Malik, Ngo, \& Kingshott, 2018), and this aspect needs unbundling, and theoretical development. Using the key search term 'crossvergence' we reviewed articles from several leading journals in the field of international HRM: APJM, HRM, HRMJ, HRMR, IMR, IJHRM, JOM and JWB and found very limited work on this topic. Leading the research on crossvergence was IJHRM, wherein we found 19 articles in total, followed by four in HRM and one in HRMJ and six in HRMR. Of these, the term 'crossvergence' was used in passing in several articles in IJHRM, HRMR and HRMJ. There were only ten articles (one in HRM by Jackson, 2002, three in HRMR and six in IJHRM) where 
crossvergence was a major focus of the research. Our analysis revealed that most studies have been undertaken in the last 15 years (ranging from 1999 to 2016), mainly after Ralston et al. $(1993,1997)$ proposed their crossvergence framework. Further, most work is focused at either the macro (country level) or micro (individual level), with little work at the firm-level but no work at the industry meso-level. This gap has also been highlighted in Mcgaughey \& De Cieri's (1999) conceptual paper. The analysis further highlights the absence of any IHRM-specific research on emerging markets such as India, and its highly successful IT industry, where, among several other industry sectors, this phenomenon can be researched.

\subsection{CDCM research and business partnerships in the IT Industry}

Both, researchers and practitioners have stressed the importance of relationships in the success of a strategic IOS partnerships. For example, a Harvard Business Review article stated that "the role of evolution of outsourcing into value-creating global collaboration provides a significant competitive advantage for those who employ it effectively" (MacCormack, Forbath, Brooks \& Kalaher, 2007, p 17). Similarly, a Price Waterhouse Cooper (PWC) report clearly suggested that "today's new breed of collaborative outsourcing partners base their relationships on clearly defined business benefits, shared risks and rewards, and increased transparency with regard to pricing, strategic planning, and joint governance" (Horowitz, Gordon, \& Kuruganti, 2008, p 2). Further, successful relationships between vendors and buyers have been often identified as a key factor in outsourcing success (Tompkins, Simonson, Tompkins, \& Upchurch, 2006) and require effective implementation and management of different practices (Knemeyer \& Murphy, 2004; Lambert, Emmelhaiz, \& Gardner, 1999). Therefore, by focusing on industry level dynamics, especially in a business-to-business context, which is typical in offshore and outsourcing relationships between firms, it is logical to study the nature and extent of collaborative partnerships. Thus, our choice of the global IT industry, where majority of the business activity and relationships are between the supplier and vendors or business-tobusiness in nature, is logical for contemporaneously studying configurations of crossvergence in service sector firms (see Boxall, 2003; Budhwar \& Debrah, 2001). The rationale behind this choice is that there are multiple levels and types of contractual partnerships, which not only makes this industry globally integrated but also one that contributes significantly towards global economic output. For example, the global IT/BPO (business process outsourcing) market grossed US\$ 2.2 trillion in 2013 (NASSCOM, 2014). In terms of its global standing and competition, in the financial year 2013-2014, the Indian IT industry comprising of over 
16,000 firms, including over 3,000 software product firms, contributed to more than 90 per cent of the global incremental growth of USD 11-12 billion (NASSCOM, 2014). As a prime destination for outsourced work, India along with several other low-cost and high skill emerging economies is a critical case for research into crossvergence of IHRM practices within the IT sector (Tung \& Haq, 2012).

Building on, meso-level variables such as industry-specific characteristics, industry dynamics and institutional arrangements, we argue for the emergence of multiple configurations of industry-specific crossvergent HRM practices in the global IT industry (Pereira \& Budhwar, 2015; Pereira \& Malik, 2015). For the purposes of this paper, therefore we focus our attention on meso-level factors such as the nature of markets served by an industry, its ownership structure, and the 'table-stakes' or key firm level organisational capabilities that can cause significant differences in IHRM practices and thus lead to the phenomenon of multivergence. Here, we argue that by unbundling industry- and firm-level dynamics one can develop an understanding of multiple configurations of crossvergence in HRM practices in different national settings. To this end, we propose several possible configurations of multivergent IHRM systems that are likely to sustain over a period of time in the global IT market. The conceptual frameworks offered here are based on a critical analysis of the extant literature and our research of more than a decade, focusing on the global IT industry. The next section outlines scenarios of CDC and multivergence from the IT industry, to show how these variously shape the IHRM practices.

\section{Strategic partnerships within offshoring: Portraying HRM practices through CDCM scenarios}

To illustrate the phenomenon of strategic partnerships within a CDCM thesis and the offshoring industry context, we utilise Pereira, Munjal, and Nandakumar's (2016) conceptual framework and typology and apply it to an offshore outsourcing context. As detailed in Figure 1, Pereira et al's (2016) theoretical framework offers a typology of strategic partnership relationships that maps different levels of such a partnership based on dependency, within an offshoring phenomenon, which we utilise using existing literature and evidence from our research and experiences as researchers and consultants in this global industry. We analyse this through the degree of dependence continuum between the client and service provider. 
Figure 1: Impact of CDMC thesis on IHRM based on dependency within outsourcing partnerships (Source: Adapted from Pereira, Munjal, \& Nandakumar, 2016)

\begin{tabular}{|c|c|c|c|}
\hline $\mathbf{H}$ & $\begin{array}{c}\text { Dependency } \\
\text { (Convergence) } \\
(\mathbf{3 . 1})\end{array}$ & & $\begin{array}{c}\text { Transformation } \\
\text { (Multivergence) } \\
(\mathbf{3 . 3})\end{array}$ \\
\hline \multirow{2}{*}{$\begin{array}{c}\text { Degree } \\
\text { of } \\
\text { 'dependence' } \\
\text { on } \\
\text { client/parent }\end{array}$} & & $\begin{array}{c}\text { Best of Both } \\
\text { (Higher Level of } \\
\text { Crossvergence) } \\
(\mathbf{2 . 2 )}\end{array}$ & \\
\hline & $\begin{array}{c}\text { Preservation } \\
\text { (Lower Level of } \\
\text { Crossvergence) } \\
(\mathbf{1 . 1 )}\end{array}$ & & $\begin{array}{c}\text { Reverse Dependency } \\
\text { (Divergence) } \\
(\mathbf{1 . 3 )}\end{array}$ \\
\hline $\mathbf{L}$ & & & \\
\hline
\end{tabular}

Degree of 'dependence' on service provider/subsidiary

\subsection{Scenario 1 (Convergence)}

With a group of US nationals working as expatriates in a subsidiary in the UK for a large US IT MNC, there are greater chances that UK's socio-cultural differences (divergence) would have a minimal impact and there would be greater chances of convergence of the US MNC's business ideologies (convergence). The differences in management practices and subsequent 'convergence' could be linked to (and what many scholars attribute this to) the 'country of origin effect', which comes about through clashes between organisational factors and local culture (Aycan, 2005). Herein, we argue that 'convergence' (Cell 3.1 of Figure 1), depicts 'dependency' between the client and the service provider.

\subsection{Scenario 2 (Divergence)}

A group of European expatriates working for a European IT MNC in Bangalore, India, has greater chances of divergence as the Indian socio-cultural differences faced by European MNCs would be significant and a small influence of European business ideologies (convergence) would be noted at the Indian subsidiary's IHRM practices suggesting crosscultural differences and the impact of national business systems (Aycan et al., 2000; Whitely, 
1999). Herein, we argue that 'divergence' (Cell 1.3 of Figure 1) depicts 'reverse dependency' between the client and the service provider. Such a scenario '...is converse to traditional centralization-based models of HQ-subsidiary relationships' and portrays '....a novel scenario where the subsidiary tends to gain greater power' (Pereira et al., 2016: 54).

\subsection{Scenario 3 (Crossvergence)}

Indian software engineers working at their Indian employer's office in Hyderabad, India for a Danish client would be expected to adapt to the Danish version of the European approach to review meetings, and to stick to Danish business practices in day-to-day communication with the client (see Laleman, Pereira \& Malik, 2015). Furthermore, when this software engineer is sent to Denmark for a limited or an extended period of time (typically, between 3 and 18 months), both the Danish client and the Indian employer would expect her/him to adapt to such a degree that no (or scarce) traces of 'Indianness' remain. However, the business ideology of getting the work done to the utmost quality and satisfaction of the client would be paramount for both parties here. This scenario, we argue, would be an ideal case where crossvergence would be prevalent and applied. Compared to the two scenarios above, the scenario here is an example of 'crossvergence' as this portrays both socio-cultural differences (divergence) as well as converging to similar business ideologies (convergence), as explained by Ralston (2008). The nature and extent of IHRM practices for managing such a workforce would need to be reviewed and modified. We argue that this scenario occurs in two situations, albeit at varying degrees i.e. as 'preservation' and as 'best of both' worlds (Cells 1.1 and 2.2 of Figure 1). In Cell 1.1 as both parties retain their distinctiveness due to high autonomy in the contractual relationship, we can expect low levels of crossvergence as 'this type of strategy is particularly relevant when the pressure for localization is high and pressure for standardization is low' (Pereira et al., 2015: 52). Relative to Cell 1.1, Cell 2.2 falls at the mid-point suggesting a hybrid or 'best of both', and a higher level of 'crossvergence' because both the client and the service provider can mutually co-exploit each other's capabilities.

\subsection{Scenario 4 (Multivergence)}

Slovenian nationals working for an Indian IT MNC headquartered in Mumbai, India, posted in Shanghai, China, working for a US client and reporting to the regional Asia-Pacific office in Sydney, Australia though she was originally recruited by the Indian MNCs European office in London, from where she was seconded. As there are six countries involved we claim that in 
such a scenario there is bound to be what we call 'multivergence' or multiple configurations of crossvergence due to the multiple socio-cultural differences (divergence) and business ideologies (convergence). Hence, owing to the nature of this global industry and by focusing on the meso-level, our scenario portrays the potential for multiple configurations of Ralston's (2008) definition of crossvergence. Herein we argue that 'multivergence' (Cell 3.3 of Figure 1) depicts a transformation such that there is a high degree of dependency between the client and the service provider. A higher level of mutual dependence demonstrates that the resources are mutually exploited to a very high degree.

\section{Crossvergence and multivergence in strategic partnerships: Meso-Level influences on IHRM}

The extant literature including our research on the global IT industry suggests that convergence in IHRM practices is influenced by a drive to set 'global industry benchmarks' in quality and information security through a combination of provider (organisational) and industry (meso) level initiatives. These include initiatives such as international quality management frameworks and global 'industry' standards and best practices. Further, divergence occurs in IHRM practices, through the differences in cultural and institutional characteristics of a new context.

Our analysis of the structure of the global IT industry reveals the domination of a few extremely large IT firms that have successfully secured long-term contracts of high dollar values from a range of industry sectors and service specialisation areas, whereas the fragmented small and medium-sized firms are able to secure short-term contracts in a narrow area of specialisation (Ethiraj et al., 2005; NASSCOM, 2016). Further, our analysis and research into the IT industry's rationale and location choices for offshoring and outsourcing suggests the presence of a dominant design choice wherein most IT software development firms deliver modularised components of IT software through relatively low-cost resource locations - for efficiency seeking MNCs. This industry-level norm requires managing the relationships between the client and service providers. The quality of relationship between the contracting parties has a significant influence on the degree of convergence, divergence or crossvergence (and multivergence) of IHRM practices.

In terms of the processes that support the CDCM thesis in the IT industry, we argue that one needs to orientate in terms of the nature of dependence on internal and external factors 
dominating the industry. Broadly, we analyse the impact of key factors at two levels: one that considers only the (internal) organisational level influences such as nature of product/service markets served, which is informed by strategic choices (Boxall, 2003) and the other that considers a wider range of (external) stakeholder influences such as its clients and other business partnerships. As a global example, the Indian IT industry depends extensively on input and resources from external clients and its network of suppliers and original equipment manufacturers. The industry relies on dynamic coordination between external vendors and clients to ensure strategic demand management of its revenue and profit streams (Banerjee, 2005). It also relies extensively on innovation through open networks for organising its work flow activities (Lema, 2010). The IT industry's reliance on external stakeholders has a profound impact, for example, in shaping its human resource development (HRD) practices (Malik, 2009). It has been noted that organisations need to reconsider their excessive focus on an inward-looking approach, which often serves a narrow set of stakeholders, oftentimes their equity owners, to an outward-looking approach, which focuses on understanding the needs of a wider group of stakeholders, such as its clients, vendors and consumers (Pereira \& Malik, 2015). What emerges as a result of this internal and external reliance is some form of crossvergence in practices between the networks of providers in the IT industry. A similar argument needs to be applied to the research and scholarship in IHRM wherein the influences in IHRM has to extend beyond the usual dyad of parent-subsidiary or buyer-vendor relationship to triads or a network approach of business partnerships in the global value chain of service delivery that is typically found in the IT industry (Lema, 2010). The need to consider the customers' or clients' latent and expressed need from a people management and development perspective has been identified earlier (e.g. Leimbach \& Baldwin, 1997) and is a widely noted gap in academic and practitioner domains (Malik 2009, Malik \& Nilakant 2011, Short, 2006, Pereira \& Malik 2015; Ulrich, 2015). Thus, adopting an outward-looking approach and undertaking research that leads to new forms of crossvergence and multivergence in IHRM practices is largely unaddressed.

Added value in goods and services occurs through customer feedback via product/process improvements and ideas for new product development. The ecosystem for such influences varies with the industry's life cycle and the dynamism in its portfolio of products and services. The global IT industry typifies an industry where firms stand to benefit immensely through the feedback from such external mechanisms. In such cases, the convergence thesis is greatly challenged by the crossvergence evident in innovative and new 
forms of work design. Similarly, divergence is also influenced from such feedback loops that are commonly noted in the services, high technology, and consumer goods industry (Baker \& Sinkula, 2002, 2005). By incorporating feedback from a range of business partnerships in its network, firms in this industry are experiencing crossvergence in their IHRM and business practices. Based on the above review and our motivations of why firms pursue global and domestic IT offshoring and outsourcing work, we present two conceptual models.

There are several implications for CDCM thesis in terms of IHRM practices. For example, can third-party contractors be managed by standardised or converging IHRM 'best-practices' of the client firm? It is envisaged that organisations offshoring work to other organisations would strive to 'justify' the basis of their decisions, through encouragement of their HR best practices for improved firm performance. What can we expect? Will there be convergence, divergence or aspects of crossvergence at the offshore locations? What is the likelihood of 'localised' and globally integrated IHRM practices to show crossvergence? Further, will there be evidence of multivergence? These questions lead us to explore the meso-level explanations in the global IT industry, as such an analysis needs unbundling to add to new knowledge on this topic, as discussed earlier.

\section{Meso-level conceptual framework}

From an industry perspective, the temporal maturity of the strength or lack thereof of organisational capabilities has an impact on subsequent choices by the outsourcers. As we know the global IT industry, like many industries, in a Porterian sense (Porter, 1985), cannot be viewed as a homogenous industry group, especially as several differences exist due to the market structure, a firm's conduct and its performance. Thus, the structure of the sub-segments in this industry, which include: IT services, IT products, research and development firms, call centres, and business process outsourcing, will most likely lead to different IHRM approaches. To some extent, these subsectors typify the degrees of work and service complexity. The complex nature of ownership in this industry is a reflection of the nature of collaborative partnerships that exist. For example, owing there are differences in nature of strategic partnerships (e.g. a third-party service provider's collaborative partnership with a client firm or an MNC's parent firm versus a collaborative partnership between an MNC's parent and its subsidiary), which may well assume the character of a joint venture or some other form of strategic business partnership and will yield to differences in the business ideology and performance between parties in a collaborative partnership. Likewise, the nature of markets served through such partnerships will also lead to different outcomes. For example, using 
Boxall's (2003) classification, mass services (low complexity), slightly differentiated services (medium complexity) and highly differentiated services (high complexity firms) in the IT services industry, we argue there will be several configurations of crossvergence (see Figure 2 ). These we argue, will ultimately have an impact on the nature and extent of its work organisation, the extent to which firms can implement high-performance work or HRM practices. Boxall (2003) argued that the opportunities for implementing high-performance work or HRM practices are highest in highly differentiated services markets that are complex in nature and thus also shape opportunities for crossvergence in HRM practices e.g. in work design. The above is one simple dimension alongside which we can expect different configurations of IHRM practices. For example, low and mass services work will require relatively limited sophistication and investment in high-performance HRM practices to be implemented by the service provider or to be adapted from the client or MNCs set of global best-practices. Relative to partnerships with MNCs, where pressure for crossvergence will be minimal, there will be medium level crossvergence likely in case of a partnerships with a local, third-party service provider for an international client.

Figure 2: Nature of partnership and work complexity: A conceptual framework for multiple configurations of crossvergence (multivergence)

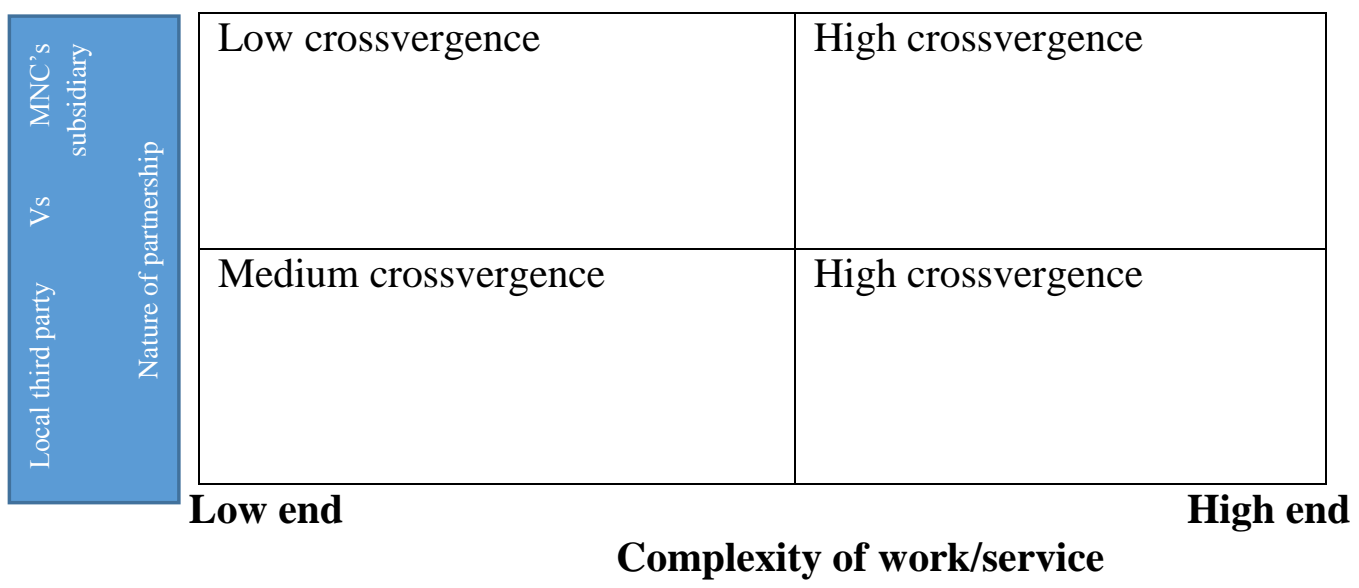

Taking another example, a local third party service provider will often report high levels of divergence and low levels of convergence due to differences in the nature of business partnership and the markets served (mass-service) (low complexity work) are highly differentiated (highly complex work). However, in this case, over time crossvergence follows as the service provider through its collaborative and strategic partnerships develops and contextualises elements of its business partner's (e.g. a client firm) work practices into its daily workflow. There will be higher levels of crossvergence in high-end and more remunerative 
work received from its clients. Similarly, MNC's subsidiaries will aim for high levels of convergence, little divergence and some crossvergence. In both nature of partnership categories, where the nature of work is complex it will mean that both parties are dealing with high levels of information asymmetry and are more likely to adopt crossvergence in IHRM practices to effectively deliver on the work specifications. As a consequence, they will most likely have medium to high levels of crossvergence. However, we argue, that even the above two conditions are not sufficient for fully explaining the multiple configurations of crossvergence i.e. what we call multivergence. The extent to which an organisation has the capabilities to modularise its products or services at a subsidiary or third-party level, the nature of its crossvergence will vary. While Boxall (2003) has argued that the natural home for implementing high performance work practices are in high-end and complex market segments, we extend this reasoning to argue that high levels of crossvergence are expected in such markets, when it comes to strategic IOS partnerships, as the nature of interaction between the service provider and the partner will be of high-involvement and working closely to deliver transformative services.

In a bid to claim legitimacy of their actions and practices with its collaborative partners, such as between the client and parent firms, the service provider and subsidiary operations often adopt aspects of IHRM practices of the client/parent MNC. Drawing from the extant literature and our own research on offshore outsourcing in the global IT/BPO industry and published research on ECM industries, the dominant design in IT offshore outsourcing has been an attempt towards modularisation of work components that are highly labour intensive in nature. The more an organisation acquires capability to modularise its workflow, the more likely it will outsource such work activities. These capabilities evolve, in part, through intra- and inter-firm knowledge and information sharing that occurs within the network of business partnerships in the IT industry. Related to the concept of modularisation, is the role of technology in digitising such modular objects. Again, numerous work activities can be digitised and delivered via the Internet or using other such technologies. In such cases, a parent firm often applies best practice models (attempting convergence) to the modularised components of such labour intensive activity. The extent to which a firm can modularise (standardise or force convergence) such activities depends on the strength of its internal organisational and managerial capabilities (or divergence due to the diversity in strategic approaches and product markets) as well as the service provider or subsidiary's quality management capabilities (Malik \& Blumenfeld, 2012; Malik, Sinha, \& Blumenfeld, 2012). 
Figure 3: Modularisation capability and nature of work: A framework for multiple configurations of crossvergence (or multivergence)

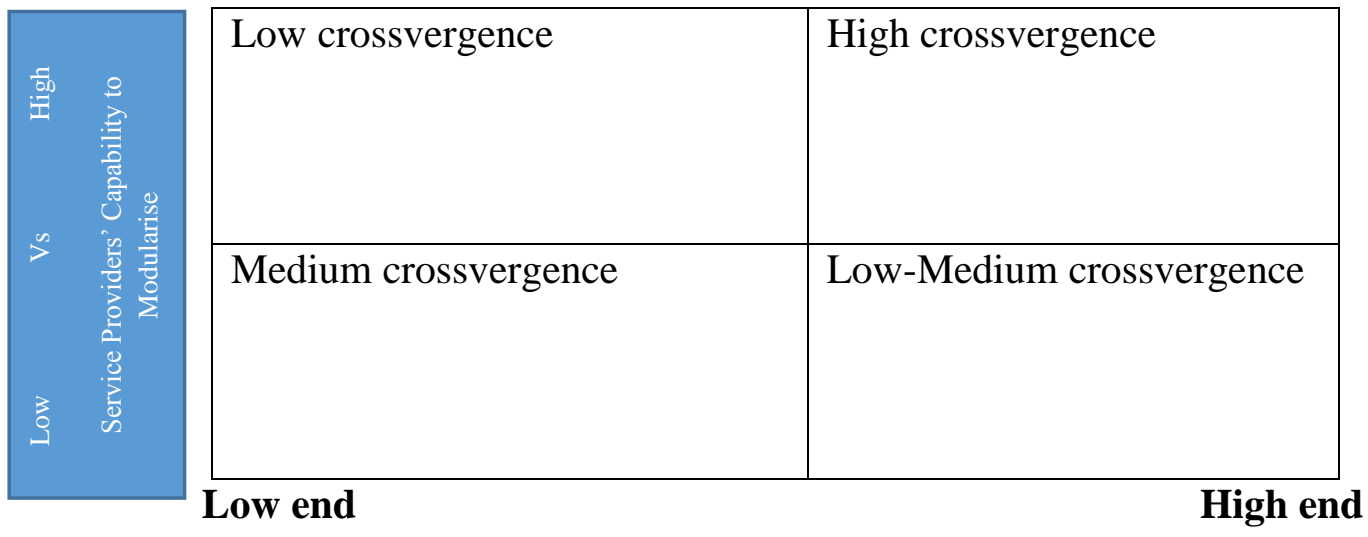

Complexity of work/service

Figure 3 shows the espoused relationship between modularisation and work complexity. Stronger modularisation capabilities are needed for work that is of higher complexity. Such capabilities evolve over time and create opportunities for crossvergence in IHRM practices of offshore service providers/subsidiaries. Further, complex work, by its very nature tends to possess high levels of information asymmetry, which often results in retaining aspects of both work practices by the collaborative partners such as a third-party service provider, a MNC's subsidiary, client firm and the MNC's parent firm. What follows from the above is that the nature of work undertaken in the industry, the types and strength of organisational capabilities to modularise work and a range of collaborative partnerships that exist in this born-global industry, all lend to and create multiple opportunities for crossvergence in IHRM practices. Higher or strong levels of such capabilities and complex high-end software or IT development work results in high degrees of crossvergence. Therefore, based on the above conceptualisations (Figures 2 and 3), in the context of offshore outsourcing global IT industry's strategic partnerships with service providers, the following future research directions in the form of propositions are proposed:

Research Proposition 1: Low levels of crossvergence are highly likely if the nature of work is one that typifies work in mass service markets. Further, in such markets, implementing bundles of high-performance HRM practices is highly unlikely. 
Research Proposition 2: High levels of crossvergence are highly likely if the nature of work is one that typifies complex and highly differentiated services. Further, in such markets, implementing bundles of high-performance HRM practices is highly likely.

Research Proposition 3: Low levels of crossvergence are highly likely in work that typifies mass service markets and if the capabilities of the service provider to modularise work are poorly developed.

Research Proposition 4: High levels of crossvergence are highly likely in the nature of work that typifies complex and highly differentiated services and if the capabilities of the service provider to modularise work are well-developed.

The notion of core competencies (Hamel \& Prahalad, 1990) is relevant to Propositions 3 and 4 which leads researchers to ask the 'what to outsource' question (Pereira \& Malik, 2015). The common areas of overlap between established capabilities of the service provider/subsidiary and the client/parent MNC can be viewed as a point where crossvergence can naturally occur. An important question here is: in deciding 'what' to outsource, what effect does this process have on crossvergence of IHRM practices in subsidiaries operating in the IT industry? Following on from the 'what' question and its impact on nature and extent of crossvergence, the 'how' question focuses on the processes and activities that are carried out at an offshore location is dependent on the business values of each contracting party, which is, in part a function of the relationship quality - both hierarchical and relational forms of governance between the contracting parties engaged in an offshore outsourcing relationship (Dibbern et al., 2004; Gopal, Sivaramakrishnan, Krishnan, \& Mukhopadhyay, 2003; Heide, 1994). Relative to hierarchical aspects (price and performance) of relationship quality, the greater the strength of the relational aspects (trust, power and commitment) of relationship quality between the contracting parties, the more likely it is that there will be some crossvergence in practices. Thus, in the context of strategic partnerships in offshore outsourcing firms, the following two research propositions are presented:

Research Proposition 5: High levels of crossvergence are highly likely in cases where relational governance (trust, power and commitment) is strong between the strategic partners. 
Research Proposition 6: Medium to low levels of crossvergence are highly likely in when hierarchical governance (price and performativity) is strong between the strategic partners.

Based on the above six future research propositions, we now discuss and conclude with key thematic areas that lead to future research ideas, based on our arguments and gaps identified within this research domain.

\section{Discussion and conclusion}

Through the above critical discussion, we can conclude that scholarship on crossvergence can benefit from a processual understanding of how this phenomenon unfolds in born-global industries. By employing a meso-level industry-based approach, we have highlighted that the learnings from this global IT industry also has relevance and application to a number of offshoring and outsourcing industries. Indeed, many globally integrated industries such as the ECM, pharmaceuticals, research and development designs for engineering, and banking, financial services and insurance industries offer fertile ground for exploring the CDCM thesis in strategic business partnerships. Managers need to focus on issues of relationship management particularly issues of trust, power and commitment in managing performance of such partnerships. There are also lessons for managers regarding the benefits that can be realised through co-exploration and co-exploitation of resources and capabilities from such partnerships. The better the managers can get at modularisation and accessing other complementary capabilities through the partnership, the more likely it will increase the success of their relationship. Further, as firms in an industry can be classified into emerging, mature and renewal phases of evolution, developing a longitudinal understanding of the key path dependencies in an industry's evolution between different nation states is critical in extending future research agenda for crossvergence (and multivergence) studies that focus on a mesolevel analysis.

This is particularly the case as the evolution of most born-global offshoring IT MNCs begins by receiving simpler and less complex tasks from its clients and gradually, as they develop more capabilities, they are able to modularise their work components received from their network of business partnerships. We further argue that differences in business ideology is a major influencer of different configurations of crossvergence as due to the wide range of collaborative partnerships, as we have discussed through our development of five scenarios 
within the five categories of partnerships with an MNC and/or a service provider (Pereira et al, 2015), one can expect different levels of crossvergence because the strategic orientation towards investing in certain organisational capabilities varies within a business partnership.

Finally, from a processual view, in addition to organisational capabilities that help in modularising work, the extent to which convergence, divergence or crossvergence might happen is also dependent on the relationship quality between the MNC and the service providers. Depending on the nature of governance approach adopted, i.e. relational or hierarchical governance-different configurations are possible. Given the complex nature of this construct, researchers need to engage in exploratory longitudinal designs and ex-post facto studies to further the understanding of crossvergence (and indeed multivergence) theses. Indepth qualitative research in such research contexts presents fertile opportunities for future research. Future research designs could consider longitudinal data collection and analysis employing dyads (MNC/subsidiary and $\mathrm{MNC} /$ service provider) or triads (MNC/service provider/subsidiary) of organisations. Given the high level of business-to-business market interactions that typify the IT industry, such as interactions between the triad of parent organisation, subsidiary and a number of collaborative partners such as clients and vendorvendee relationships in their network, there is a need to focus more on the influence of the vendor in a business partnership. Li, Wei, and Liu (2010:1458) argue that the "extant literature on cross-border outsourcing has been conducted mainly from the vendees' perspective", and not those that provide such services. Such research was undertaken to basically explore how outsourcers in developed Western countries transfer their knowledge from onshore resources to offshore resources for many reasons to achieve cost cutting (Chua \& Pan, 2008), improve organisational focus (Kakabadse \& Kakabadse, 2005), achieve corporate transformation (e.g. Khan \& Fitzgerald, 2004; Linder, 2004) and align their sourcing activities to develop future capabilities (Howell, James \& Malik, 2003). Thus, the extant literature on outsourcing provides little understanding about how diverse strategic alignments and their interface impact the 'knowledge acquisition of vendors' (Li, Wei \& Liu, 2010: 1458). In such a situation there is a dire need for research that identifies what drives crossvergence of HRM from a 'vendors' perspective, especially from emerging markets such as India (Lahiri et al., 2012) and from its global IT industry. This gives rise to our first future research idea, i.e future research should focus on the meso-level (industry and firm-level) influences of vendors from emerging markets on crossvergence in IHRM practices. 
As is widely recognised gap in the literature on this topic (Ralston, 2008; Witt, 2008), future research will benefit from longitudinal designs for explicating crossvergence in IHRM practices. There is also a dearth of longitudinal qualitative case-based designs for understanding the processes that lead to crossvergence. Such in-depth longitudinal cases could bring out rich insights for future theoretical development (see for example, longitudinal research in the IT industry by Pereira and Anderson (2012), Pereira and Scott (2015) and Pereira, Munjal, and Nadakumar (2016). Hence, the second future research idea should focus on: the need to utilize longitudinal methodological designs which can help identify the drivers of crossvergence in IHRM practices.

Identifying a gap in the extant literature on MNCs and international management, Almond (2011: 531) argues that within international HRM research “..."local” here almost always refers to national culture and/or institutions in host countries. The potential effects of the economic governance of sub-national geographies on IHRM have largely escaped analysis". Thus, HRM in MNCs can substantially be affected by sub-national factors, which also impact on the transfer of HR practices, policies, architecture, skills, competencies, etc. within its foreign subsidiaries. This novel form of convergence, divergence crossvergence or multivergence of HRM is under researched and would be found in the IT industry where locational (offshoring) choices or offerings are varied and are based and involves new cities, geographies etc., in a single country. According to Almond (2011) certain formal sub-national variations such as those in existence in the US (right-to-work), some Eastern European countries (special economic zones) and the UK (greenfield sites) may also exist in the nature of business and employment regulation as applied to MNCs. Emerging economies such as China and India have also largely followed this path in their respective inward outsourcing strategies. Though not a new phenomenon, sub-national variations have increased recently, largely aided by globalising processes that have increased the embeddedness of MNC units in local economies (Almond, 2011). This context would bring out interesting findings, which identifies what drives the convergence, divergence crossvergence or multivergence of HRM and the reasons for them. Additionally, the proximity of institutional infrastructure, such as universities and other research organisations, training systems, etc., to MNCs aid in the flexible, responsive capacity building needed to develop innovative productive capacity. Accordingly, we propose our third future research idea, i.e. how sub-national geographies in IHRM influence crossvergence in IHRM practices. 
According to Budhwar (2012: 2514) “multinational companies (MNCs) are known to establish country-specific headquarters (CSHQs) or centres to create and transfer knowledge in order to better co-ordinate and control their operations, and also to share knowledge between affiliates both within and outside the country". In terms of the literature on IHRM in MNC affiliates operating or head-quartered in emerging markets, Budhwar (2012: 2516), states that some work has been done in countries such as China, the Czech Republic, Hungary, Poland, Russia, Malaysia, Vietnam, India, Greece and Jordan, variously focusing on the transfer of HR across subsidiaries, the role of HR in the success of joint ventures, contribution of HR towards organisational performance and issues related to recruitment, culture fit and managing host country nationals. This area is vastly under researched as such CSHQs could have massive influences when it comes to the convergence, divergence crossvergence or multivergence of HRM, especially in the IT industry. For example, the culture and management styles at CSHQ could differ from the MNCs actual HQ, and hence there could be crossvergence. However, as previously seen (e.g., Budhwar, Schuler \& Sparrow 2009), there is a gap in the literature when it comes to HR in affiliates of MNCs operating in emerging markets. Moreover, with the exception of Björkman and Lu (1999) and Sparrow (2006), few studies have concentrated on the role of HR in the country-specific centres of MNCs, with none in the Indian context (Budhwar, 2012). Therefore, the final future research idea should focus on: evaluating the influence of CSHQs in the IT industry in terms of crossvergence in IHRM practices in subsidiary operations.

In conclusion, this paper makes three distinctive contributions. First, by providing an overview of the key gaps in crossvergence thesis this paper highlights the relevance of multivergence in strategic business partnerships within the global IT sector. Second, this study develops a framework for analysis of multivergence in strategic partnerships within the global IT sector that can be generalised to other high tech sectors. And third, by highlighting the key challenges, this study presents testable future research propositions and ideas for this complex, topical and important area of scholarship.

\section{References}

Al Ariss, A., \& Sidani, Y. (2014). Divergence, Convergence, or Crossvergence in International Human Resource Management. Human Resource Management Review. Call for papers

Al Ariss, A., \& Sidani, Y., (2016a). Divergence, convergence, or crossvergence in international human resource management Human Resource Management Review 26, 283-84. 
Al Ariss, A., \& Sidani, Y., (2016b). Comparative international human resource management: Future research directions, Human Resource Management Review, 26, 352-358.

Aklamanu, A., Degbey, W. Y., \& Tarba, S. Y. (2016). The role of HRM and social capital configuration for knowledge sharing in post-M\&A integration: A framework for future empirical investigation. The International Journal of Human Resource Management, 27, 2790-2822.

Almond, P. (2011). Re-visiting 'country of origin' effects on HRM in multinational corporations. Human Resource Management Journal, 21, 258-271.

Angwin, D. N., Mellahi, K., Gomes, E., \& Peter, E. (2014). How communication approaches impact mergers and acquisitions outcomes. The International Journal of Human Resource Management, this issue. doi: 10.1080/09585192.2014.985330

Ahlstrom, D., Levitas, E., Hitt, M. A., Dacin, M. T., \& Zhu, H. (2014). The three faces of China: Strategic alliance partner selection in three ethnic Chinese economies. Journal of World Business, 49, 572-585.

Aycan, Z. (2005). The interplay between cultural and institutional/structural contingencies in human resource management practices. International Journal of Human Resource Management, 16, 1083-1119.

Aycan, Z., Kanungo, R. N., Mendonca, M., Yu, K., Deller, J., Stahl, G. \& Khursid, A. (2000). Impact of culture on human resource management practices: A ten country comparison. Applied Psychology: An International Review, 49, 192-221.

Baker, W. E., \& Sinkula, J. M. (2002). Market orientation, learning orientation and product innovation: Delving into the organisation's black box. Journal of Market-Focussed Management, 5, 5-23.

Baker, W. E., \& Sinkula, J. M. (2005). Market orientation and the new product paradox. Journal of Product Innovation Management, 22, 483-502.

Banerjee, P. (2004). The Indian software industry: Business strategy and dynamic coordination. New Delhi, India: Palgrave-MacMillan.

Björkman, I., \& Lu, Y. (1999). A corporate perspective on the management of human resource in China. Journal of World Business, 34, 16-25.

Blumenberg, S., Beimborn, D., \& Koenig, W. (2008, January). Determinants of IT outsourcing relationships: a conceptual model. In Hawaii International Conference on System Sciences, Proceedings of the 41st Annual (pp. 12-12). IEEE.

Boxall, P. (2003). HR strategy and competitive advantage in the service sector. Human Resource Management Journal, 13, 5-20.

Boxall, P. (2012). High-performance work systems: what, why, how and for whom? Asia Pacific Journal of Human Resources, 50, 169-186.

Boxall, P., \& Macky, K. (2007). High-performance work systems and organisational performance: bridging theory and practice. Asia Pacific Journal of Management, 45, 261-270.

Boxall, P., \& Macky, K. (2009). Research and theory on high-performance work systems: progressing the high-involvement stream. Human Resource Management Journal, 19, 323.

Boxall, P., \& Purcell, J. (2000). Strategic human resource management: where have we come from and where should we be going? International Journal of Management Reviews, 2, 183-203.

Boxall, P., \& Purcell, J. (2003). Strategy and Human Resource Management. Basingstoke and New York: Palgrave Macmillan.

Brewster, C., Mayhorfer, W., \& Cooke, F.L. (2015) Convergence, divergence and diffusion of HRM in emerging markets. In F. Horwitz and P. Budhwar (Eds.) Handbook of human resource management in emerging markets. Edward Elgar, 451-469. 
Brewster, C., Sparrow, P., \& Harris, H. (2005). Towards a new model of globalizing HRM, The International Journal of Human Resource Management, 16, 949-970.

Briscoe, D., Schuler, R., \& Tarique, I. (2012). International human resource management, Routledge, New York.

Budhwar, P. \& Debrah, Y. (2001) Rethinking comparative and cross national human resource management research. The International Journal of Human Resource Management, 12, 497-515.

Budhwar, P. \& Sparrow, P. (2002). An integrative framework for determining cross-national human resource management practices. Human Resource Management Review, 12, 377 403.

Budhwar, P. (2012). Management of human resources in foreign firms operating in India: the role of HR in country-specific headquarters. The International Journal of Human Resource Management, 23, 2514-2531.

Budhwar, P., Schuler, R., \& Sparrow, P. (2009). Editors Introduction: Developments in Cross-National Comparative HRM. In P. Budhwar, R. Schuler, \& P. Sparrow (Eds.), In Major Works in International Human Resource Management (pp. 7-13). London: Sage.

Budhwar, P. S., Varma, A., \& Katou, A. A. (2009). The role of HR in cross-border mergers and acquisitions: The case of Indian pharmaceutical firms. Multinational Business Review, 17, 89-110.

Bunyaratavej, K., Hahn, E., \& Doh, J. (2007). International offshoring of services: A parity study. Journal of International Management, 13, 7-21.

Cappelli, P., Singh, H., Singh, J., \& Useem, M. (2010). The India way: lessons for the U.S. Academy of Management Perspectives, 24, 6-25.

Carmel, E., \& Agarwal, R., (2002). The maturation of offshore sourcing of information technology work. MIS Quarterly Executive, 1, 65-77.

Carroll, G. R., \& Hannan, M. T. (eds). (1995). Organizations in industry: Strategy, structure and selection. New York and Oxford: Oxford University Press.

Chand, M., \& Katou, A. A. (2012). Strategic determinants for the selection of partner alliances in the Indian tour operator industry: A cross-national study. Journal of World Business, 47, 167-177.

Chua, A. L., \& Pan, S. L. (2008). Knowledge transfer and organizational learning in IS offshore sourcing. Omega, 36, 267-281.

Contractor, F. J., \& Woodley, J. A. (2015). How the alliance pie is split: Value appropriation by each partner in cross-border technology transfer alliances. Journal of World Business, $50,535-547$.

Cooke, F. L. (2014). Chinese multinational firms in Asia and Africa: Relationships with institutional actors and patterns of HRM practices. Human Resource Management, 53, 877-896.

Croom, S. R. (2001). The dyadic capabilities concept: examining the processes of key supplier involvement in collaborative product development. European Journal of Purchasing \& Supply Management, 7, 29-37.

Dibbern, J., Goles, T., Hirschheim, R., \& Jayatilaka, B. (2004). Information systems outsourcing: a survey and analysis of the literature. ACM SIGMIS Database, 35, 6-102.

Dickmann, M., Bewster, C., \& Sparrow, P. (2008). International human resource management: A European perspective. Hoboken: Taylor \& Francis.

Doh, J. (2005). Offshore outsourcing: implications for international business and strategic management theory and practice. Journal of Management Studies, 42, 695-704.

Dowling, P., Festing, M., \& Engle, S. A. (2013). International human resource management. Thomson Learning. 
Entrekin, L., \& Chung, Y. W. (2001). Attitudes towards different sources of executive appraisal: A comparison of Hong Kong Chinese and American managers in Hong Kong. International Journal of Human Resource Management, 12, 965-987.

Fiss, P. C. (2007). A set-theoretic approach to organisational configurations. Academy of Management Review, 32, 1180-1198.

Fitzgerald, D., \& Willcocks, L., (1994). Outsourcing information technology: contracts and the client/vendor relationship. Oxford Institute of Information Management 1-20.

Githens, R. P., Dirani, K., Gitonga, J., \& Teng, Y. (2008). Technology-related research in HRD publications: an analysis of content and metaperspectives from 2000 to 2006. Human Resource Development Quarterly, 19, 191-216.

Gopal, A., Sivaramakrishan, K., Krishnan, M., \& Mukhopadhyay, T. (2003). Contracts in offshore software development: An empirical analysis. Management Science, 49, 167183.

Gomes, E., Cohen, M., \& Mellahi, K. (2011). When two African cultures collide: A study of interactions between managers in a strategic alliance between between two African organizations. Journal of World Business, 46, 5-12.

Gomes, E., Angwin, D., Peter, E., \& Mellahi, K. (2012). HRM issues and outcomes in African mergers and acquisitions: A study of the Nigerian banking sector. The International Journal of Human Resource Management, 23, 2874-2900.

Gomes, E., Angwin, D., Weber, Y., \& Yedidia Tarba, S. (2013). Critical success factors through the mergers and acquisitions process: Revealing pre- and post-M\&A connections for improved performance. Thunderbird International Business Review, 55, 13-35.

Gospel, H., \& Sako, M. (2010). The unbundling of corporate functions: the evolution of shared services and outsourcing in human resource management. Industrial and Corporate Change, 19, 1367-1396.

Graf, M., \& Mudambi, S. (2005). The outsourcing of IT enabled business processes: A conceptual model of the location decision. Journal of International Management, 11, 253-268.

Hall, P. A., \& Soskice, D. (Eds.). (2001). Varieties of capitalism: The institutional foundations of comparative advantage. Oxford University Press.

Hansen, M. T., Nohria, N., \& Tierney, T. (1999). What's your strategy for managing knowledge? Harvard Business Review, 77, 106-116.

Harbison, F., \& Myers, C. (1959) (eds.) Management in the Industrialized World. NY: McGraw Hill. Hätönen, J., \& Eriksson, T. (2009). 30+ years of research and practice of outsourcing - Exploring the past and anticipating the future. Journal of International Management, 15, 142-155.

Henderson, J. C. (1990). Plugging into strategic partnerships: the critical IS connection. MIT Sloan Management Review, 31, 7.

Heide, J. B. (1994). Interorganizational governance in marketing channels. The Journal of Marketing, 71-85.

Holcomb, T. R., \& Hitt, M. A. (2007). Toward a model of strategic outsourcing. Journal of operations management, $25,464-481$.

Hollingsworth, J. R., \& Streeck, W. (1994), Countries and Sectors: Concluding Remarks on Performance, Convergence and Competitiveness, New York: Oxford University Press.

Howell, J., James, A., \& Malik, K. (2003). The sourcing of technological knowledge: distributed innovation processes and dynamic change. $R \& D$ Management, 33, 395-403.

Jaeger, A., Kim, S., \& Butt, A., (2016). Leveraging values diversity: The emergence and implications of a global managerial culture in global organizations. Management International Review, 56, 227-254. 
Jackson, T. (2002). The management of people across cultures: valuing people differently. Human Resource Management, 41, 455-475.

Jackson, T., Louw, L., \& Zhao, S. (2013). China in sub-Saharan Africa: implications for HRM policy and practice at organizational level. The International Journal of Human Resource Management, 24, 2512-2533.

Kakabadse, A., \& Kakabadse, N. (2005). Outsourcing: Current and future trends. Thunderbird International Business Review, 47, 183-204.

Kaplan, D. M. \& Lerouge, C. (2007). Managing on the edge of change: Human resource management of information technology employees. Human Resource Management, 46, 325-330.

Katz, D., \& Kahn, R. L. (1978). The social psychology of organizations. (2nd ed.), New York: Wiley.

Kedia, B.L., \& Lahiri, S., (2007). International Outsourcing of Services: a partnership model. Journal of International Management, 13, 22

Kneymeyer, A., \& Murphy, P. (2004). Explaining the performance of third-party logistics arrangements: A relationship marketing perspective. Journal of Supply Chain Management, 40, 35-51.

Kerr, C., Dunlop, J., Harbison, F., \& Myers, C. (1960) Industrialism and Industrial Man. London: Heinemann.

Khan, N., \& Fitzgerald, G. (2004). Dimensions of offshore outsourcing business models. Journal of Information Technology Cases and Applications, 6, 35-50.

Kim, Y., \& Gao, F. Y. (2010). An empirical study of human resource management practices in family firms in China. The International Journal of Human Resource Management, 21, 2095-2119.

Kotabe, M., \& Murray, J. (2004). Global sourcing strategy and sustainable competitive advantage. Industrial Marketing Management, 33, 7-14.

Laleman, F., Pereira, V., \& Malik, A. (2015). Understanding cultural singularities of 'Indianness' in an intercultural business setting. Culture and Organization, DOI: 10.1080/14759551.2015.1060232, 2-21.

Lambert, D., \& Emmelhianz, M., \& Gardner, J. (2004). Building successful logistics partnerships. Journal of Business Logistics, 20, 165-181.

Lahiri, S., Kedia, B., \& Mukherjee, D. (2012). The impact of management capability on the resource-performance linkage: Examining Indian outsourcing providers. Journal of World Business, 47, 145-155.

Leimbach, M. P., \& Baldwin, T. T. (1997). How research contributes to the HRD value chain, In R. A. Swanson \& E. F. Holton, III (Eds.), Human resource development: A research handbook. San Francisco, CA: Berrett-Koehler.

Li, Y., Wei, Z., \& Liu, Y. (2010). Strategic Orientations, Knowledge Acquisition, and Firm Performance: The Perspective of the Vendor in Cross-Border Outsourcing. Journal of Management Studies, 47, 1457-1482.

Linder, J. (2004). Outsourcing as a strategy for driving transformation. Strategy and Leadership, 32, 26-31.

Malik, A. (2009). Training drivers, competitive strategy and clients' needs: Case studies of three business process outsourcing organisations. Journal of European Industrial Training, 33, 160-177.

Malik, A., \& Nilakant, V. (2011). Extending the 'size matters' debate: Drivers of training in three business process outsourcing SMEs in India. Management Research Review, 34, $111-132$

Malik, A., \& Rowley, C. (2015). Business models and people management in the Indian IT industry: From people to profits. London: Routledge. 
Malik, A., Sinha, A., \& Blumenfeld, S. (2012). Role of quality management capabilities in developing market-based organisational learning capabilities: Case study evidence from four Indian business process outsourcing firms. Industrial Marketing Management, 41, 639-648.

Mcgaughey, S. L., \& Cieri, H. D. (1999). Reassessment of convergence and divergence dynamics: Implications for international HRM. International Journal of Human Resource Management, 10, 235-250.

McGraw, P., \& Peretz, M. (2011). HRD practices in local private sector companies and MNC subsidiaries in Australia, 1996-2009. The International Journal of Human Resource Management, 22, 2539-2557.

Mudambi, S. M., \& Tallman, S. (2010). Make, Buy or Ally? Theoretical Perspectives on Knowledge Process Outsourcing through Alliances. Journal of Management Studies, 47, $1434-1456$.

NASSCOM Strategic Review Report. (2014). NASSCOM, Accessed website on 9th September 2014 http://www.nasscom.in/sites/default/files/researchreports/SR14Exec_Summary.pdf.

Nikandrou, I., \& Papalexandris, N. (2007). The impact of M\&A experience on strategic HRM practices and organisational effectiveness: Evidence from Greek firms. Human Resource Management Journal, 17, 155-177.

Nobeoka, K., Dyer, J., \& Madhok, A. (2002). The influence of customer scope on supplier learning and performance in the Japanese automobile industry. Journal of International Business Studies, 33, 717-736.

Parmigiani, A., \& Rivera-Santos, M. (2011). Clearing a path through the forest: A metareview of interorganizational relationships. Journal of Management, 37, 1108-1136.

Pak, Y. S., Ra, W., \& Lee, J. M. (2015). An integrated multistage model of knowledge management in international joint ventures: Identifying a trigger for knowledge exploration and knowledge harvest. Journal of World Business, 50, 180-191.

Pereira, V., \& Anderson, V. (2012). A longitudinal examination of HRM in a human resources offshoring (HRO) organization operating from India. Journal of World Business, 47, 223-231.

Pereira, V., \& Budhwar, P. (2015). HRM and firm performance: The case of Indian IT/BPO industry. In Malik, A., \& Rowley, C., (ed.), The changing face of business models and people management in the Indian IT industry: From people to profits. Routledge, London.

Pereira, V., \& Malik, A. (2015). Human capital in Indian IT/BPO industry. Palgrave Macmillan, London.

Pereira, V., \& Scott, P. (2014). Neither Western not Indian: HRM policy in an Indian multinational. In: Konara, P., Yoo, J.H., McDonald, F. and Wei, Y., eds. The rise of multinationals from emerging economies: achieving a new balance. Palgrave Macmillan, Basingstoke. ISBN 9781137473103.

Pereira, V., Munjal, S. \& Nandakumar, M. K. (2016). Reverse dependency: A longitudinal case study investigation into Headquarter-Subsidiary relationship in the context of an emerging country. International Studies of Management \& Organization, 46(1) 50-62.

Quinn, J.B., Hilmer, F.G., (1994). Strategic outsourcing. Sloan Management Review Summer, $33-55$.

Ralston, D. A. (2008). The crossvergence perspective: Reflections and projections. Journal of International Business Studies, 39, 27-40.

Ralston, D. A., Gustafson, D. J., Cheung, F. M., \& Terpstra, R. H. (1993). Differences in managerial values: A study of US, Hong Kong and PRC managers. Journal of International Business Studies, 249-275. 
Ralston, D. A., Holt, D. H., Terpstra, R. H., \& Kai-Cheng, Y. (1997). The impact of national culture and economic ideology on managerial work values: A study of the United States, Russia, Japan, and China. Journal of International Business Studies, 177-207.

Ramamoorthy, N., Gupta, A., Sardessai, R. M., \& Flood, P. C. (2005). Individualism/collectivism and attitudes towards human resource systems: a comparative study of American, Irish and Indian MBA students. The International Journal of Human Resource Management, 16, 852-869.

Ramamurti, R. (2004). Developing countries and MNEs: extending and enriching the research agenda. Journal of International Business Studies, 35, 277-283.

Rowley, C., \& Benson, J. (2000) (eds.) Globalisation and Labour in the Asia Pacific, London: Cass.

Sarala, R. M., Junni, P., Cooper, C. L., \& Tarba, S. Y. (2016). A sociocultural perspective on knowledge transfer in mergers and acquisitions. Journal of Management, 42, 1230-1249.

Short, D. (2006). The gap between research and practice in HRD: A summary of the discussion 1995-2005. In Proceedings of the 2006 International Academy of HRD Conference. Bowling Green, OH: AHRD.

Sparrow, P. (2006). 'Global Knowledge Management and HRM,' in Handbook of Research in International HRM, eds. G. Stahl and I. Bjo“rkman, Cheltenham: Palgrave, pp. 113138.

Søderberg, A. M., Krishna, S., \& Bjørn, P. (2013). Global software development: commitment, trust and cultural sensitivity in strategic partnerships. Journal of International Management, 19, 347-361.

Stokes, P., Liu, Y., Smith, S., Leidner, S., Moore, N., \& Rowland, C. (2015). Managing talent across advanced and emerging economies: HR issues and challenges in a Sino-German strategic collaboration. The International Journal of Human Resource Management. doi:10.1080/09585192.2015.1074090

Tarba, S. Y., Ahammad, M. F., Junni, P., Stokes, P., \& Morag, O. (2017). The Impact of Organizational Culture Differences, Synergy Potential, and Autonomy Granted to the Acquired High-Tech Firms on the M\&A Performance. Group \& Organization Management, 1059601117703267.

Tompkins, J., Simonson, S., Tompkins, B., \& Upchurch, B. (2006). Relationships: The key to outsourcing success. Supply Chain Management Review, 45, 13T-22T.

Tung, R. L., \& Haq, R. (2012). International assignments to/from India: do race and gender matter?. The International Journal of Human Resource Management, 23, 221-235.

Vance, C. M., Chow, I. H. S., Paik, Y., \& Shin, K. Y. (2013). Analysis of Korean expatriate congruence with Chinese labor perceptions on training method importance: implications for global talent management. The International Journal of Human Resource Management, 24, 985-100.

Vasilaki et al. (2016). The moderating role of transformational leadership on HR practices in M\&A integration. The International Journal of Human Resource Management, 27, 24882504.

Weber, Y., \& Tarba, S.Y. (2010). Human resource practices and performance of mergers and acquisitions in Israel. Human Resource Management Review, 20, 203-211.

Witt, M. (2008). Crossvergence 10 years on: impact and further potential. Journal of International Business Studies, 39, 47-52

Xing, Y., Liu, Y., Tarba, S. Y., \& Cooper, C. L. (2016). Intercultural influences on managing African employees of Chinese firms in Africa: Chinese managers' HRM practices. International Business Review, 25, 28-41. 
Yahiaoui, D., Chebbi, H., \& Weber, Y. (2016). HR practices, context and knowledge transfer in M\&A. The International Journal of Human Resource Management. doi: 10.1080/09585192.2016.1226192

Zhang, M. (2012). The development of human resource management in China: An overview. Human Resource Management Review, 22, 161-164.

Zhang, J., Ahammad, M. F., Tarba, S., Cooper, C. L., Glaister, K. W., \& Wang, J. (2015). The effect of leadership style on talent retention during merger and acquisition integration: Evidence from China. The International Journal of Human Resource Management, 26, 1021-1050.

Zhou, Y., Zhang, Y., \& Liu, J. (2012). A Hybridism model of differentiated human resource management effectiveness in Chinese context. Human Resource Management Review, 22, 208-19.

Whitley, R. (1999). Divergent capitalisms: The social structuring and change of business systems, Oxford: Oxford University Press. 